\title{
LIFE HISTORY OF BANGGAI CARDINALFISH, PTERAPOGON KAUDERNI (ACTINOPTERYGII: PERCIFORMES: APOGONIDAE), FROM BANGGAI ISLANDS AND PALU BAY, SULAWESI, INDONESIA
}

\author{
Samliok NDOBE ${ }^{1,2^{*}}$, SOEMARNO ${ }^{1}$, Endang Y. HERAWATI ${ }^{1}$, Daduk SETYOHADI ${ }^{1}$, \\ Abigail MOORE ${ }^{3}$, Maria L.D. PALOMARES ${ }^{4}$, and Daniel PAULY ${ }^{4}$ \\ ${ }^{1}$ Faculty of Marine and Fisheries Science, Brawijaya University, Malang, Indonesia \\ ${ }^{2}$ Faculty of Animal Husbandry and Fisheries, Tadulako University, Palu 94118, Indonesia \\ ${ }^{3}$ Fisheries and Marine Science Institute (STPL), Palu 94118, Indonesia \\ ${ }^{4}$ Sea Around Us Project, Fisheries Centre, University of British Columbia, Vancouver, Canada
}

Ndobe S., Soemarno, Herawati E.Y., Setyohadi D., Moore A., Palomares M.L.D., Pauly D. 2013. Life history of Banggai cardinalfish, Pterapogon kauderni (Actinopterygii: Perciformes: Apogonidae), in Banggai Islands and Palu Bay, Sulawesi, Indonesia. Acta Ichthyol. Piscat. 43 (3): 237-250.

Background. The paternal mouthbrooding Banggai cardinalfish, Pterapogon kauderni Koumans 1933, has an exceptionally restricted endemic range for a marine fish, is traded internationally as a marine ornamental and listed as endangered in the IUCN Red List. This paper aims to contribute to the body of knowledge regarding the biology of this species, based on studies on the endemic population in the Banggai Archipelago and the introduced population in Palu Bay, Central Sulawesi Province, Indonesia.

Materials and methods. Length frequency data collected over the period 2004-2012 $(n=23230)$ were analysed using the ELEFAN approach (FiSAT software). A length-weight relation was derived from measurements of 1002 individuals from the Banggai Archipelago. Specimens from the Palu Bay population were used to study reproductive parameters $(n=80)$, morphometric relations $(n=54)$ and feeding habits $(n=30)$.

Results. The ELEFAN analysis suggested an annual recruitment peak (September to December) and VBGF parameter estimates of $L_{\infty}=7.1 \mathrm{~cm}(\mathrm{SL}), K=0.74$ year $^{-1}$ and $t_{0}=-0.11$ year, suggesting first maturity at 1 year,

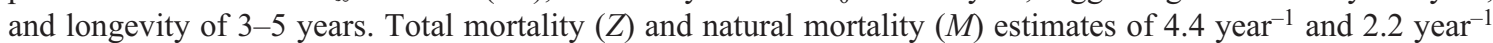
yielded fishing mortality $F=2.2$ year $^{-1}$ and exploitation rate $E=0.5$. Length-weight relation parameters were: $a=0.18 ; b=2.15$. There was no significant morphological difference between sexes. Gonad maturation began at $2.9-3.5 \mathrm{~cm} \mathrm{SL}$, all specimens $\geq 4.2 \mathrm{~cm} \mathrm{SL}$ were sexually mature. Mean observed fecundity $(59, n=21)$ and number of eggs brooded by males $(59, n=17)$ were similar. Observed sex ratio was 1.67 males per female. Gut content indicated an omnivorous, predominantly carnivorous diet. Copepods and decapod larvae were the most abundant components in adult $(\mathrm{SL} \geq 4.2 \mathrm{~cm})$ and sub-adult $(\mathrm{SL} \leq 4.2 \mathrm{~cm})$ diets respectively. Adult diet appeared to be more varied. No empty guts were observed.

Conclusion. This study provides data for a major reassessment of Pterapogon kauderni life history parameters in FishBase, the global database of fishes. P. kauderni spawning is associated with the lunar cycle; the seasonal recruitment peak is probably related to improved reproductive success during the calm season. With strong indications of a decline in the endemic population due to habitat degradation and loss (independent of fishing pressure), current exploitation levels may be unsustainable. Research is required to further refine life-history parameters (e.g. sex ratio) and elucidate issues such as fasting in brooding male Banggai cardinalfish and ontogenetic differences in diet.

Keywords: growth, mortality, length-frequency, ELEFAN, length-weight relation, maturity, reproduction, diet and feeding habits

\section{INTRODUCTION}

The Banggai cardinalfish, Pterapogon kauderni Koumans, 1933, is a small and visually attractive shallowwater reef fish, popular in the marine aquarium trade. The known endemic distribution is extremely limited for a marine fish, with $\pm 30 \mathrm{~km}^{2}$ of habitat spread over around 32 small islands within an area of $\pm 5500 \mathrm{~km}^{2}$ (Vagelli 2008). Introduced populations have become established along

\footnotetext{
* Correspondence: Ir. Samliok Ndobe, M.Si., Fakultas Peternaken dan Perikanan, Universitas Tadulako, Kampus Bumi Tadulako, Palu 94118, Sulawesi Tengah, Indonesia, phone: +624514744436, fax: +624514131334, e-mail: samndobe@yahoo.com (soe.marno@yahoo.co.id, eyulih@yahoo.co.id, dsetyohadi@yahoo.com, abigai12105@yahoo.com,m.palomares@fisheries.ubc.ca,d.pauly@fisheries.ubc.ca).
} 
several trade routes, including at least two sites in Palu Bay (Moore and Ndobe 2007). The Banggai cardinalfish is a paternal mouth-brooder with direct development and without pelagic dispersal phase, as the larvae, on release, swiftly seek refuge in nearby substrate (Vagelli 1999). Post-release, Banggai cardinalfish maintain a sedentary lifestyle with high site fidelity (Kolm et al. 2005).

Considered at risk of extinction in the wild due to over-exploitation for the marine aquarium trade (Lunn and Moreau 2004) and habitat degradation (Moore et al. 2011, 2012), international concern has led to listing of the Banggai cardinalfish as endangered in the IUCN (International Union for the Conservation of Nature) Red List (Allen and Donaldson 2007). While a number of studies have been published on various aspects of Pterapogon kauderni biology and ecology, literature on specific Banggai cardinalfish life-history traits, both in its endemic distribution area and for the introduced populations, remains limited, as reflected by the paucity of life history data in FishBase (Froese and Pauly 2013). This paper presents data on life-history parameters of $P$. kauderni including growth, mortality, reproduction, and diet, based on research carried out over 8 years (2004-2012) in the Banggai Archipelago and in Palu Bay, Central Sulawesi Province, Indonesia. This information will contribute to the knowledge base for conservation management of the species.

\section{MATERIALS AND METHODS}

Sampling. Banggai cardinalfish, Pterapogon kauderni, specimens were captured at Bone Baru, Banggai Island and in Palu Bay (Fig. 1) using a 'cang'-style mobile fyke net, such as used in the ornamental fishery ${ }^{*}$. The dates and coordinates for each site as well as the number of fish captured, post-capture treatment, and use in this study are given in Table 1, and the habitats defined as follows:

- Coral reef (CR): coral reef area near the reef crest or upper slope;

- Reef flat (RF): flat or slightly sloping areas shoreward from the reef crest, substrate dominated by coral or dead coral and rubble;

- Seagrass (SG): areas shoreward from the reef crest, substrate usually predominantly sandy with visually obvious seagrass cover, some coral and/or rubble;

- Mangrove (MG): between the prop roots of Rhizophora sp., mainly below the low-tide line.

Length-frequency data were also obtained from belt transect surveys (transect size $20 \mathrm{~m} \times 5 \mathrm{~m}=100 \mathrm{~m}^{2}$, census of fish within transect) carried out over the period 2004-2012. The number of fish, month, and year are shown in Table 1. The sea surface temperature (SST) and other environmental parameters at the sampling sites are given in Table 2.

Growth and mortality. The available length frequency data were regrouped into $6 \mathrm{~mm}$ classes $(0-5.9 ; 6-11.9$, etc., with class mid-lengths [ML] at 3, 9, etc.; see Table 3), then analysed using the FISAT II software (Gayanilo et al. 2005) to obtain estimates of the parameters of the von
Bertalanffy Growth Function (VBGF), of the form

$$
L_{t}=L_{\infty} \cdot\left(1-\mathrm{e}^{-K\left(t-t_{0}\right)}\right) \quad \text { [1] }
$$

where: $L_{\infty}$ is the mean length the fish would attain is they were to live indefinitely, $K\left(\right.$ time $\left.^{-1}\right)$ is the rate at which $L_{\infty}$ is approached, and $t_{0}$ the predicted 'age' at a length (or weight) of zero (Pauly 1984). Specifically, $L_{\infty}$ was estimated from a Wetherall Plot (Wetherall 1986) as implemented in FiSAT II, $K$ was estimated by its 'scanning for $\mathrm{K}$ routine', and $t_{0}$ was estimated by solving equation [1] for a size at known age, once $L_{\infty}$ and $K$ had been estimated (see below). Note also that longevity $\left(t_{\max }\right)$, if it is assumed to be the age at which fish reach $95 \%$ of $L_{\infty}$, can be approximated by $t_{\max } \approx 3 \cdot K^{-1}$ (Pauly 1984).

Comparisons between pairs of $L_{\infty}$ and $K$ estimates were performed using an index of growth performance ( $\left.\varnothing^{\prime}\right)$ defined by the formula proposed by Pauly $(1983,2010)$ : $\varnothing^{\prime}=\log (K)+2 \cdot \log \left(L_{\infty}\right)$

Natural mortality $(M)$ was estimated from the empirical equation (Pauly 1980):

$\log (M)=-0.0066-0.279 \cdot \log \left(L_{\infty}\right)+0.6543 \cdot \log (K)$

$+0.4634 \cdot \log (T)$

where: $L_{\infty}$ is expressed in cm, $K$ is in year ${ }^{-1}$, and $T$ is the mean water temperature, in ${ }^{\circ} \mathrm{C}$.

Total mortality $(Z)$ was then estimated using a lengthconverted catch curve (Pauly and Ingles 1981), thus allowing fishing mortality (from $Z-M=F$ ) and exploitation rate (from $E=F \cdot Z^{-1}$ ) to be estimated as well.

Length-weight relation and other morphometrics. The parameters ' $a$ ' and ' $b$ ' of a length-weight relation of the form $W=a \cdot L^{b}$

where: $W$ is the wet weight in $\mathrm{g}$ and $L$ is the standard length (SL) in $\mathrm{cm}$, were determined from the analysis of 1002 Banggai cardinalfish specimens collected from Bone Baru in the Banggai Archipelago. The length $(L)$ of each specimen was measured to the nearest millimetre $(\mathrm{mm})$. The specimens were then weighed to the nearest $0.1 \mathrm{~g}$, and the weights averaged within each mm length class. A linear regression was then fitted to the log-transformed variables, i.e., $L$ and the corresponding (mean) weights, which leads to an equation of the form $\log (W)=\log (a)+b \cdot \log (L)$

Fifty four specimens from Kadongo in Palu Bay were measured to the nearest $\mathrm{mm}$ to relate their standard length to a number of other morphometric features (Fig. 2). The ratios of each measurement to standard length were then calculated, and averaged for females $(n=27)$, males $(n=27)$ and for the entire sample $(n=54)$. The ratios for females and males were compared using one-way analysis of variance (ANOVA). Linear regression was performed for the ratio of total length to standard length $\left(\mathrm{TL} \cdot \mathrm{SL}^{-1}\right)$. Reproductive biology. Each specimen $(n=80)$ was dissected and the gonad removed and weighed. The gonadosomatic index (GSI) was calculated from

$\mathrm{GSI}=W_{\mathrm{g}} \cdot W^{-1}$

where: $W_{\mathrm{g}}$ is the gonad weight and $W$ is the total body weight. Eggs were counted in both females (in developing egg masses) and males (in their buccal cavities). In juvenile specimens, where sex was not visually apparent, his-

\footnotetext{
* See: Sulawesi Case Study—Banggai Kepulauan (Bangkep). Pp. 5-143 and pp.169-228 In: Indonesian ornamental fish trade: Case studies and options for improving livelihoods while promoting sustainability in Banggai and Banyuwangi. The international seafood trade: Supporting sustainable livelihoods among poor aquatic resource users in Asia (EC Prep Project EP/RO3/R14). Available from http://aquaticcommons.org/2247/1/IndonesianOrnamentalFishTrade_opt.pdf.
} 
tological preparations were made and examined under a binocular microscope $(4 \times 20$ magnification $)$. The eggs contained in the egg sacs were clearly visible beside mature and maturing ovaries; this yielded fecundity (number of eggs in female specimens). This was complemented by effective fertility (number of eggs brooded by males), size at first maturity and sex ratio (number of males $\times$ number of females ${ }^{-1}$ ) of the sample.

Feeding habits. Specimens from the Palu Bay population used in the feeding study $(n=30)$ were measured and weighted (see above), and their gut tract was then removed and assessed as to its fullness, which ranged from very full to near empty (there were no empty guts).
Each gut tract was then weighed (to the nearest $0.01 \mathrm{~g}$ ), and the gut contents separated using $70 \%$ alcohol (4 drops) and prepared for examination under a $(4 \times 10$ magnification) binocular microscope. Food item identification was based mainly on Sachlan (1972).

\section{RESULTS}

Environmental parameters. All specimens of Pterapogon kauderni were collected from shallow (maximum $6 \mathrm{~m}$ ) coastal waters, mainly embayments or lagoons or other habitats sheltered from strong wave action (e.g., mangrove stands). Environmental parameter values at the sites where P. kauderni samples were collected are given in Table 2.

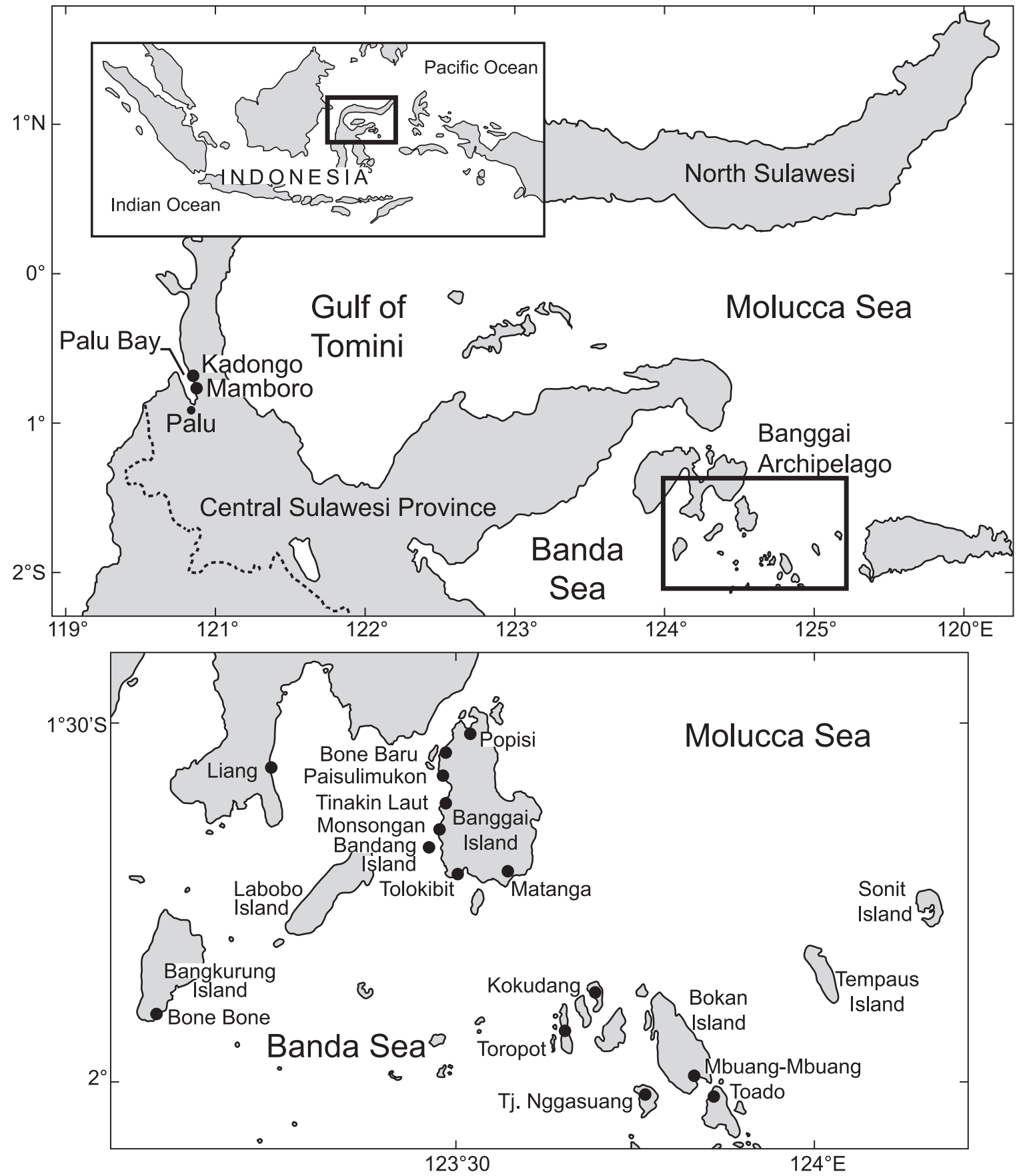

Fig. 1. Map of Central Sulawesi, showing the locations of the sampling sites mentioned in the text and tables of this contribution 
The observed water temperature range was $26-31^{\circ} \mathrm{C} . \quad K=0.74$ year $^{-1}$ (Fig. 3). Given these parameter values, Despite a preponderance of readings of $29^{\circ} \mathrm{C}$, the average solving the VBGF [equation 1] for a length of $4 \mathrm{~cm}$ at temperature in $P$. kauderni habitat is probably $28^{\circ} \mathrm{C}$, given 1 year (taken to be the mean length and age at first matuthat temperatures are lower at night, when few samples rity respectively, see below) yields an estimated $t_{0} \approx-0.11$. were taken. Salinity was in the PSS 29-35 range at all Thus, the growth in SL of P. kauderni can be described by sites and in all seasons where measurements were taken. $L_{t}=7.1 \cdot\left(1-\exp ^{-(0.74(t+0.11))}\right)$

Growth and mortality. The largest specimen found in which implies a longevity of 3-5 years.

this study also seems to be the largest specimen of Pterapogon kauderni reported to date. This specimen, a female, provided a value of $L_{\max }=6.6 \mathrm{~cm}(\mathrm{SL})$ and $8.6 \mathrm{~cm}(\mathrm{TL})$, and a weight of $11.3 \mathrm{~g}$.

Total mortality $Z$ was 4.4 year $^{-1}$ (Fig. 4). Subtracting $M$, estimated for a temperature of $28^{\circ} \mathrm{C}$ as 2.2 year $^{-1}$, yields an estimate of $F$ as 2.2 year $^{-1}$ and an $E$ of 0.5 .

Length-weight relation and other morphometrics. The

The analysis of the length-frequency data in Table 31002 Banggai cardinalfish, Pterapogon kauderni, in this yielded $\mathrm{SL}_{\infty}=7.1 \mathrm{~cm}$ (or $\mathrm{TL}_{\infty}=10.7 \mathrm{~cm}$; Table 4 ) and study ranged from $1 \mathrm{~cm}$ to $6 \mathrm{~cm}$. The 48 log-transformed

Table 1

Details on samples of Banggai cardinalfish, Pterapogon kauderni, collected from 2008 to 2011 in Central Sulawesi

\begin{tabular}{|c|c|c|c|c|c|}
\hline $\begin{array}{l}\text { Date }[\mathrm{D} / \mathrm{M} / \mathrm{Y}] \\
\text { (time) }\end{array}$ & Sampling site & $\begin{array}{l}\text { Latitude/ } \\
\text { Longitude }\end{array}$ & Fish sampled & Field treatment & Primary use \\
\hline $\begin{array}{l}29 / 10 / 08 \\
(1000-1300)\end{array}$ & $\begin{array}{l}\text { Mamboro } \\
\text { (Palu Bay) }\end{array}$ & $\begin{array}{l}0^{\circ} 47^{\prime} 51^{\prime \prime} \mathrm{S} \\
119^{\circ} 52^{\prime} 14^{\prime \prime} \mathrm{E}\end{array}$ & 30 & Preserved in $70 \%$ alcohol & Diet study \\
\hline $\begin{array}{l}12 / 05 / 09 \\
24 / 05 / 09 \\
17 / 07 / 09 \\
31 / 07 / 09 \\
(0900-1200)\end{array}$ & $\begin{array}{l}\text { Kadongo } \\
\text { (Palu Bay) }\end{array}$ & $\begin{array}{l}0^{\circ} 44^{\prime} 51^{\prime \prime} \mathrm{S} \\
119^{\circ} 51^{\prime} 21^{\prime \prime} \mathrm{E}\end{array}$ & $\begin{array}{l}20 \\
20 \\
20 \\
20\end{array}$ & Preserved in $70 \%$ alcohol & $\begin{array}{l}\text { Reproductive } \\
\text { biology }\end{array}$ \\
\hline $\begin{array}{l}26 / 12 / 11 \\
(1500-1700)\end{array}$ & Bone Baru & $\begin{array}{l}1^{\circ} 31^{\prime} 53^{\prime \prime} \mathrm{S} \\
123^{\circ} 29^{\prime} 35^{\prime \prime} \mathrm{E}\end{array}$ & 1003 & $\begin{array}{l}\text { Fixed in formalin } \\
(4 \% \text { for } 24 \mathrm{~h}) \\
\text { then preserved } \\
\text { in } 70 \% \text { alcohol }\end{array}$ & $\begin{array}{l}\text { Growth } \\
\text { parameters }\end{array}$ \\
\hline
\end{tabular}

Environmental parameters at Banggai cardinalfish, Pterapogon kauderni,

Table 2 sample collection sites (Central Sulawesi)

\begin{tabular}{|c|c|c|c|c|c|c|}
\hline Site & $\begin{array}{l}\text { Month/ } \\
\text { Year }\end{array}$ & $\begin{array}{l}\text { Time of day } \\
{[\mathrm{GMT}+8]}\end{array}$ & $\begin{array}{l}\text { SST } \\
{\left[{ }^{\circ} \mathrm{C}\right]}\end{array}$ & $\begin{array}{l}\text { Depth } \\
{[\mathrm{m}]}\end{array}$ & $\begin{array}{l}\text { Salinity } \\
\text { [psu] }\end{array}$ & $\begin{array}{l}\text { Habitat/ } \\
\text { Ecosystem }\end{array}$ \\
\hline Popisi & \multirow{7}{*}{$12 / 2011$} & 0800 & 28 & $0.5-1.5$ & 34 & $\mathrm{CR}, \mathrm{RF}, \mathrm{SG}$ \\
\hline Bone Baru & & $\begin{array}{l}0700 \\
1500\end{array}$ & $\begin{array}{l}28 \\
29\end{array}$ & $0.5-3$ & 32 & $\mathrm{CR}, \mathrm{RF}, \mathrm{SG}$ \\
\hline Paisulimukon & & 1100 & 29 & $0.5-3$ & 34 & $\mathrm{CR}$ \\
\hline Tinakin Laut & & 0830 & 28 & $1-2$ & $33-34$ & RF, SG \\
\hline Monsongan & & 1130 & 29 & $1-2$ & 34 & RF, SG \\
\hline Tolokibit & & 1100 & 29 & $1-2$ & $30-32$ & RF, SG \\
\hline Matanga & & 1300 & 29 & $1-2 \mathrm{~m}$ & $31-32$ & $\mathrm{RF}, \mathrm{SG}$ \\
\hline Tinakin Laut & $04 / 2007$ & $0830-1730$ & $30-31$ & $0.5-3$ & $32-35$ & $\mathrm{CR}, \mathrm{RF}, \mathrm{SG}$ \\
\hline Tanjung Nggasuang & \multirow{7}{*}{$06 / 2012$} & 1000 & 29 & $1-3$ & 33 & Lagoon \\
\hline Kokudang & & 0830 & 29 & $1-3$ & 34 & $\mathrm{CR}, \mathrm{RF}, \mathrm{SG}$ \\
\hline Toropot & & 1230 & 29 & $1-2$ & - & $\mathrm{SG}$ \\
\hline Mbuang-Mbuang & & 1200 & 29 & $1-2$ & - & SG, sand \\
\hline Toado & & 1000 & 29 & $1-2$ & 33 & $\mathrm{MG}, \mathrm{RF}$ \\
\hline Bone Bone & & 0930 & 29 & $0.5-3$ & - & RF, SG, sand \\
\hline P. Bandang & & 1040 & 28 & $0.5-6$ & - & $\mathrm{CR}, \mathrm{RF}, \mathrm{SG}$ \\
\hline Mamboro & $\begin{array}{l}11 / 2006 \\
10 / 2008\end{array}$ & Monitoring (24 h) & $26-31$ & $0.5-4$ & $29-34$ & $\mathrm{CR}, \mathrm{SG}$ \\
\hline Kadongo & $\begin{array}{l}05 / 2009 \\
07 / 2009\end{array}$ & 1030 & 29 & $1-3$ & 32 & $\mathrm{CR}, \mathrm{RF}, \mathrm{SG}$ \\
\hline
\end{tabular}

$\mathrm{GMT}=$ Greenwich mean time, $\mathrm{SST}=$ sea surface temperature, $\mathrm{CR}=$ coral reef, $\mathrm{RF}=$ reef flat, $\mathrm{SG}=$ seagrass, $\mathrm{MG}=$ mangrove. 
data pairs used for the analysis are shown in Fig. 5, along with the linear regression $\log (W)=2.151 \cdot \log (\mathrm{SL})-$ 0.744 ( $r=0.993)$, from which the relation $W=0.18 \cdot L^{2.15}$ can be derived. Thus, the growth in (wet) weight of $P$. kauderni can be described by $W_{\mathrm{t}}=12.2 \cdot\left(1-\exp ^{-(0.74(t+0.11))}\right)^{2.15}$

Figure 6 illustrates the growth in length and weight of P. kauderni as inferred from the data presented so far.
Morphometric parameters and weight of the specimens measured in this study are given in Table 4 for females and males. Differences between males and females in average values of the ratios calculated were not significant $\left(F<F_{\text {crit, } \alpha=0.05}=4.03\right)$, except for the mouth 8] gape (MG) to standard length ratio $\left(F=7.52>F_{\text {crit }, \alpha=0.01}\right.$ $=7.15 ; P=0.0083)$. There was no significant difference between the $\mathrm{TL} \cdot \mathrm{SL}^{-1}$ ratio for males and females

Standard length-frequency data of Banggai cardinalfish, Pterapogon kauderni, sampled

Table 3 in the Banggai Archipelago over the period of 2004-2012 based on 6-mm size classes

\begin{tabular}{|c|c|c|c|c|c|c|c|c|c|c|c|}
\hline \multirow{2}{*}{$\begin{array}{l}\mathrm{ML} \\
{[\mathrm{mm}]}\end{array}$} & \multicolumn{2}{|c|}{2004} & \multicolumn{2}{|c|}{2006} & \multicolumn{3}{|c|}{2007} & \multirow{2}{*}{$\begin{array}{c}2009 \\
\text { Sep }\end{array}$} & \multicolumn{2}{|c|}{2011} & \multirow{2}{*}{$\frac{2012}{\text { Jun }}$} \\
\hline & Oct & Nov & Nov & Dec & Apr & Jul & Oct & & Sep & Dec & \\
\hline 3 & 0 & 0 & 0 & 0 & 0 & 0 & 0 & 0 & 0 & 0 & 0 \\
\hline 9 & 14 & 9 & 77 & 21 & 76 & 72 & 75 & 13 & 84 & 542 & 685 \\
\hline 15 & 17 & 10 & 141 & 194 & 161 & 59 & 101 & 21 & 89 & 581 & 989 \\
\hline 21 & 12 & 8 & 151 & 177 & 355 & 84 & 112 & 86 & 98 & 1301 & 2586 \\
\hline 27 & 11 & 7 & 109 & 96 & 291 & 70 & 89 & 69 & 91 & 1213 & 1874 \\
\hline 33 & 9 & 6 & 39 & 46 & 153 & 67 & 78 & 36 & 79 & 409 & 1325 \\
\hline 39 & 7 & 8 & 48 & 35 & 118 & 114 & 69 & 49 & 98 & 533 & 577 \\
\hline 45 & 9 & 17 & 94 & 84 & 296 & 129 & 64 & 84 & 39 & 567 & 1174 \\
\hline 51 & 13 & 19 & 135 & 91 & 248 & 147 & 125 & 91 & 40 & 396 & 2173 \\
\hline 57 & 3 & 7 & 25 & 10 & 57 & 9 & 39 & 5 & 6 & 38 & 165 \\
\hline 63 & 0 & 0 & 0 & 0 & 1 & 0 & 0 & 0 & 0 & 0 & 6 \\
\hline Total & 95 & 91 & 819 & 754 & 1756 & 751 & 752 & 454 & 624 & 5580 & 11554 \\
\hline
\end{tabular}

$\mathrm{ML}=$ class mid- length $(n=23230)$.

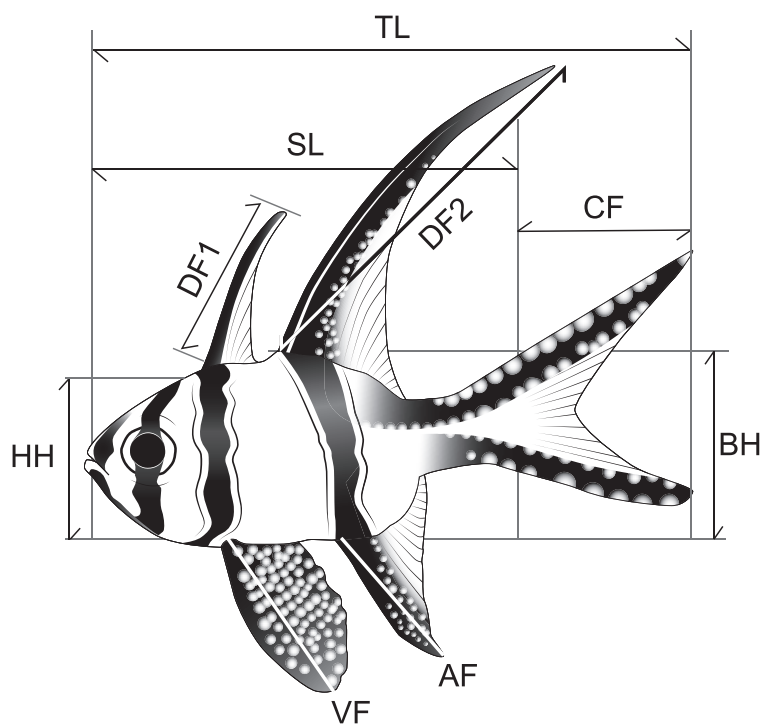

Fig. 2. Schematic representation of a specimen of Banggai cardinalfish, Pterapogon kauderni, illustrating where measurements were taken; TL = total length; $\mathrm{SL}=$ standard length; $\mathrm{HH}=$ head height; $\mathrm{BH}$ = body height; $\mathrm{CF}=$ caudal fin length; DF1 = anterior dorsal fin length; $\mathrm{DF} 2$ = posterior dorsal fin length; $\mathrm{VF}=$ ventral fin length; $\mathrm{AF}=$ anal fin length; $\mathrm{PL}=$ pectoral fin length (not shown) and $\mathrm{MG}=$ mouth gape (not shown)

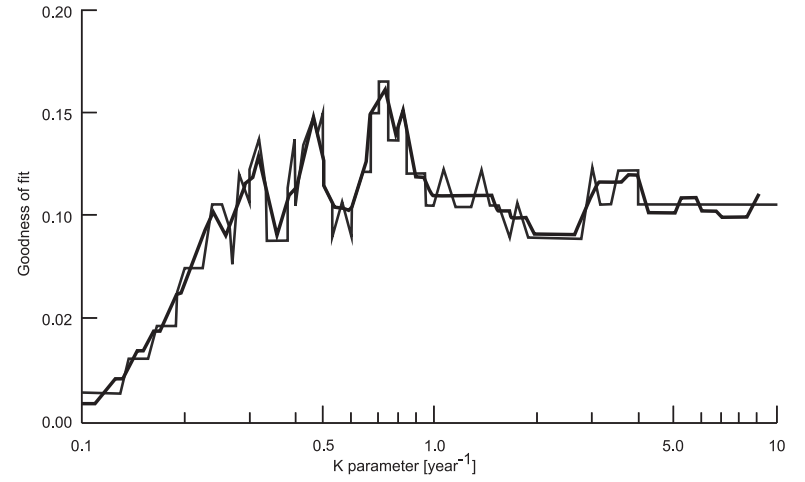

Fig. 3. Output of the ELEFAN software routine scanning for the optimal estimates of $K$ for Banggai cardinalfish, Pterapogon kauderni, given $\mathrm{SL}_{\infty}=7.1 \mathrm{~cm}$ and the length-frequency data in Table 3; The best estimate of $K=0.74$ year $^{-1}$, corresponding to a longevity of $3-5$ years 
$\left(F=0.007<F_{\text {crit }, \alpha=0.05}=4.03\right)$. The mean value of the ratio of TL to $\mathrm{SL} \pm \mathrm{SD}$ expressed in percentage points was $\approx 150 \pm 12$ and linear regression of TL versus SL yielded a slope \pm SE of $1.5 \pm 0.1$ with an $r^{2}$ of $0.99(n=54)$. The mean aspect ratio (standard length divided by body height $) \pm \mathrm{SE}$ was $2.07 \pm 0.02$ for the total sample $(N=54)$ and was not significantly correlated with length $\left(r^{2}=0.001\right)$ or $\operatorname{sex}\left(F=1.01<F_{\text {crit }, \alpha=0.05}=4.03\right)$.

Reproductive biology. A synopsis of the data on female Pterapogon kauderni gonad development is shown in Table $5(n=30)$. The (single) gonad shape and size was similar in male and female $P$. kauderni, varying in colour (paler in males) and texture (granulose in females). Developing masses encased in an egg envelope were present in most adult female specimens. Mature male and female $P$. kauderni gonads photographed during this study are shown in Fig. 7.

Effective fertility based on numbers of eggs or larvae brooded by male specimens (13 specimens collected from Bone Baru and 4 brooding males collected at Kadongo) ranged from 45 to 99 eggs, with a mean value \pm SE of $59 \pm 2.7$ eggs or larvae. Several other males captured during the length/weight study were also brooding however the eggs or larvae were released on capture and could not be recovered for counting. The smallest of these had an SL of $4.2 \mathrm{~cm}$.

A regression of fecundity and fertility against body size (SL or $W$ ) showed no significant trend $(P>0.05$, $\left.r^{2}<0.1\right)$, and thus fecundity in adult $P$. kauderni can be summarized by their mean fecundity \pm SE $(58 \pm 4$ eggs per female). The similarity between fertility estimates based on numbers of eggs in female gonads and eggs/larvae brooded by male P. kauderni indicates that few (if any) eggs are lost in the process of fertilisation and transfer to the male buccal pouch. The sex ratio of the (random) sample $(n=80)$ was 1.67 , i.e., heavily biased towards males.

Table 6 shows the percentages of occurrence of various stages of gonad development in male P. kauderni. Male gonad development began at $\mathrm{SL} \approx 3 \mathrm{~cm}$ and all male

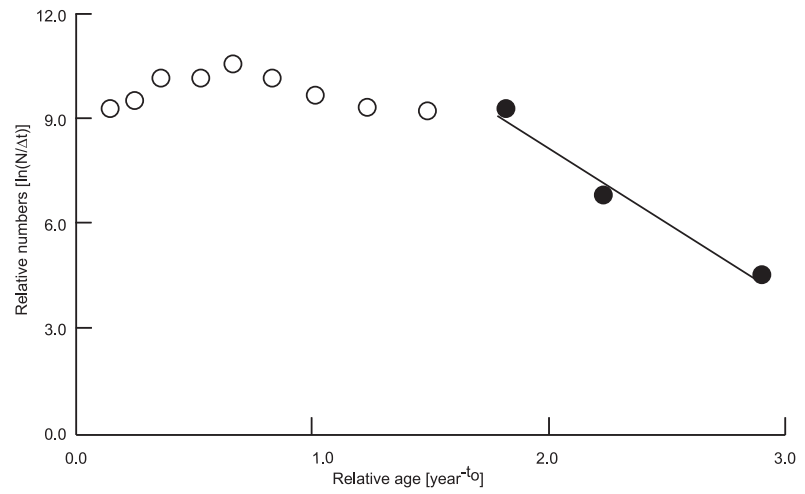

Fig. 4. Length-converted catch curve for Banggai cardinalfish, Pterapogon kauderni, as used to estimate $Z=4.4$ year $^{-1}$ from the 3 largest length classes

Table 4

Standard length (SL), weight $(W)$ and 13 morphometric ratios (expressed as percentages)

for 27 male and 27 female Banggai cardinalfish, Pterapogon kauderni, and significance levels of a one-way analysis of variance (ANOVA) for male $\left({ }^{\lambda}\right)$ versus female $(+)$ specimens

\begin{tabular}{|c|c|c|c|c|c|c|c|}
\hline \multirow{2}{*}{ Parameter } & \multicolumn{3}{|c|}{$\begin{array}{l}\text { Adult Male } P . \text { kauderni } \\
(n=27 ; \text { SL: } 4.3-5.4 \mathrm{~cm})\end{array}$} & \multicolumn{3}{|c|}{$\begin{array}{l}\text { Adult Female } P . \text { kauderni } \\
(n=27 ; \text { SL: } 4.1-5.7 \mathrm{~cm})\end{array}$} & \multirow{2}{*}{$\begin{array}{c}\text { ANOVA } \\
\hat{0}-q\end{array}$} \\
\hline & Average & $\mathrm{SD}$ & $\mathrm{SE}$ & Average & SD & SE & \\
\hline $\mathrm{SL}[\mathrm{cm}]$ & 4.86 & 0.33 & 0.06 & 4.87 & 0.43 & 0.08 & $\mathrm{~ns}$ \\
\hline$W[\mathrm{~g}]$ & 4.89 & 1.23 & 0.24 & 4.78 & 1.34 & 0.26 & $\mathrm{~ns}^{\mathrm{c}}$ \\
\hline $\mathrm{TL} \cdot \mathrm{SL}^{-1}[\%]$ & 150.43 & 12.38 & 2.38 & 150.17 & 10.50 & 2.02 & ns \\
\hline $\mathrm{DF} 1 \cdot \mathrm{SL}^{-1}[\%]$ & 36.03 & 6.14 & 1.18 & 33.84 & 5.18 & 1.00 & ns \\
\hline $\mathrm{DF} 2 \cdot \mathrm{SL}^{-1}[\%]$ & 74.23 & 15.25 & 2.94 & 66.85 & 18.09 & 3.48 & $\mathrm{~ns}$ \\
\hline $\mathrm{PF} \cdot \mathrm{SL}^{-1}[\%]$ & 26.49 & 6.18 & 1.19 & 25.10 & 3.55 & 0.68 & ns \\
\hline $\mathrm{VF} \cdot \mathrm{SL}^{-1}[\%]$ & 45.34 & 4.65 & 0.90 & 44.30 & 3.88 & 0.75 & ns \\
\hline $\mathrm{AF} \cdot \mathrm{SL}^{-1}[\%]$ & 38.59 & 6.38 & 1.23 & 38.41 & 6.91 & 1.33 & $\mathrm{~ns}$ \\
\hline $\mathrm{CF} \cdot \mathrm{SL}^{-1}[\%]$ & 49.73 & 7.26 & 1.40 & 46.84 & 6.27 & 1.21 & ns \\
\hline $\mathrm{HH} \cdot \mathrm{SL}^{-1}[\%]$ & 37.13 & 6.78 & 1.30 & 37.19 & 4.87 & 0.94 & ns \\
\hline $\mathrm{MG} \cdot \mathrm{SL}^{-1}[\%]$ & 27.89 & 2.77 & 0.53 & 25.51 & 3.58 & 0.69 & vs \\
\hline $\mathrm{TL} \cdot \mathrm{BH}^{-1}[\%]^{\mathrm{a}}$ & 3.06 & 0.29 & 0.06 & 3.14 & 0.28 & 0.05 & ns \\
\hline $\mathrm{SL} \cdot \mathrm{BH}^{-1}[\%]^{\mathrm{b}}$ & 2.04 & 0.19 & 0.04 & 2.09 & 0.16 & 0.03 & $\mathrm{~ns}$ \\
\hline $\mathrm{MG} \cdot \mathrm{SL}^{-1}$ range & \multicolumn{3}{|c|}{$22.73 \%-32.65 \%$} & \multicolumn{3}{|c|}{$19.51 \%-33.33 \%$} & \\
\hline
\end{tabular}

$\mathrm{SD}=$ standard deviation; $\mathrm{SE}=$ standard error; $\mathrm{ns}=$ not significant $\left(F<F_{\text {crit }, \alpha=0.05}=4.03\right)$; vs $=$ very significant $(F=7.52$ $>F_{\text {crit }, \alpha=0.01}=7.15 ; P=0.00835<0.01 ; n=$ number of fish measured; TL = total length; $\mathrm{SL}=$ standard length; DF1 = anterior dorsal fin; $\mathrm{DF} 2=$ posterior dorsal fin; $\mathrm{PF}=$ pectoral fin; $\mathrm{AF}=$ anal fin; $\mathrm{CF}=$ caudal fin; $\mathrm{HH}=$ head height; $\mathrm{MG}=$ mouth gape; $\mathrm{BH}=$ body height; ${ }^{\mathrm{a}}$ average aspect ratio for $\mathrm{TL}(n=54)=3.10(\mathrm{SD}=0.28 ; \mathrm{SE}=0.04) ;{ }^{\mathrm{b}}$ average aspect ratio for SL $(n=54)=2.07(\mathrm{SD}=0.18 ; \mathrm{SE}=0.02) ;{ }^{\mathrm{c}}$ ANOVA male vs. female for $\mathrm{SL}^{3} \cdot W^{-1}$ was also not significant. 
specimens with a SL of $4 \mathrm{~cm}$ or above were either repro- $(n=28)$ were either currently producing egg masses ductively active (brooding and/or spent) or appeared $(n=24)$, including the smallest female over $4 \mathrm{~cm}$ SL physically capable of reproduction. Female gonad devel- $(4.1 \mathrm{~cm} \mathrm{SL})$, or appeared to have recently spawned $(n=4)$. opment was less well documented, due to sample size Overall, this suggests that mean length at first maturity of (Table 5). However, both female specimens in the SL male and female P. kauderni is about $4 \mathrm{~cm}$ SL, as $3.1-3.5 \mathrm{~cm}$ size class had gonads in the early stages of assumed above for the estimation of $t_{0}$.

development, and all female $P$. kauderni over $4 \mathrm{~cm}$ SL Feeding habits. Quantitative gut content data for the sub-

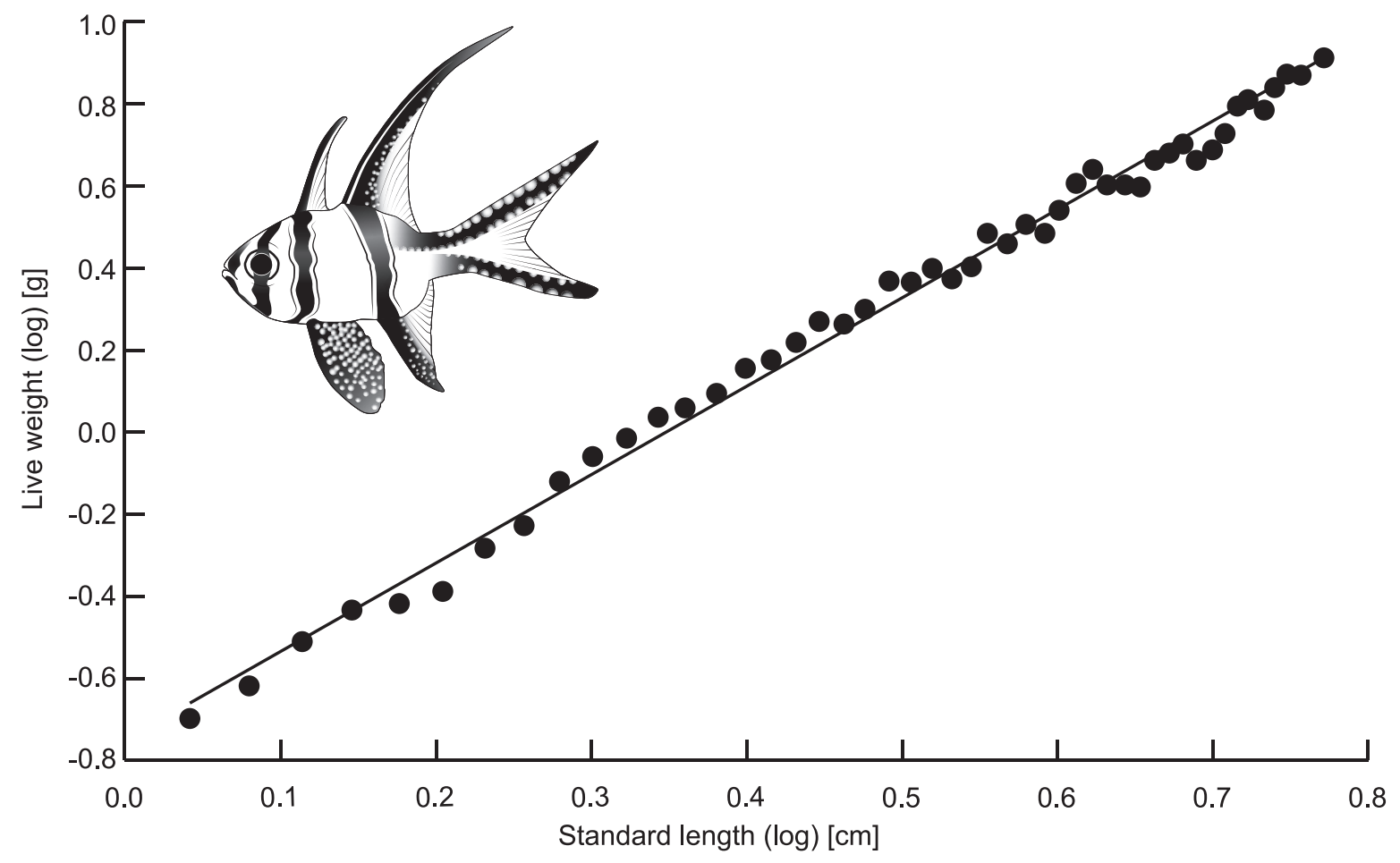

Fig. 5. Data points and log transformed length-weight relation in Banggai cardinalfish, Pterapogon kauderni, i.e., $\log (W)=-0.744+2.151 \cdot(\log L)$, with $r^{2}=0.993 ; n=1002 ;$ Standard error SE of slope $=0.025$

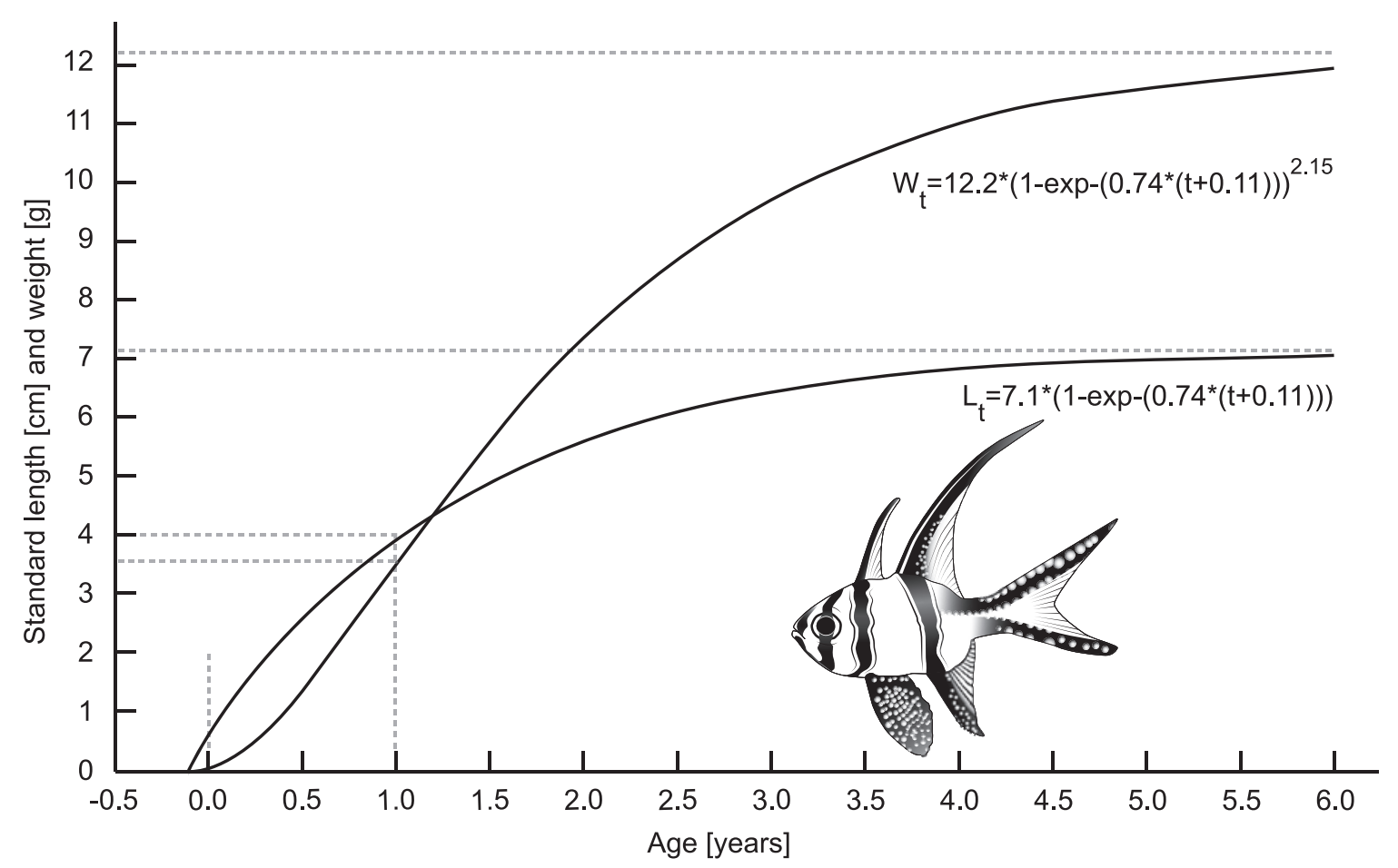

Fig. 6. Estimated mean growth curves in length and weight of Banggai cardinalfish, Pterapogon kauderni 
adult (SL $<4.2 \mathrm{~cm}, n=9$ ) and adult ( $\mathrm{SL} \geq 4.2 \mathrm{~cm}, n=21$ ) was within the range for which growth and survival of specimens are shown in Tables 7 and 8. Trophic level Pterapogon kauderni juveniles reared in captivity was could not be calculated due to the lack of volume/weight acceptable but higher than the value (PSS 27) for which data and the substantial proportion of unidentified items.

\section{DISCUSSION}

growth and survival were highest (Madinawati et al. 2009).

Growth, mortality, and life cycle. The estimated asympEnvironmental parameters. Water quality parameters recorded by the authors i.e., $6.6 \mathrm{~cm}$, in Palu Bay, but were within normal limits for tropical marine fishes and appears reasonable for this species. Overall, the growth coral reef ecosystems. The observed salinity (PSS 29-35) parameters and $M$ that were estimated here suggest that

Table 5

Gonad development and fecundity of female Banggai cardinalfish, Pterapogon kauderni,

in Palu Bay $(n=30)$

\begin{tabular}{|c|c|c|c|c|c|c|}
\hline $\begin{array}{l}\text { Moon phase } \\
\text { (date) }\end{array}$ & Sample no. & $\begin{array}{c}\mathrm{SL} \\
{[\mathrm{cm}]}\end{array}$ & $\begin{array}{c}W \\
{[\mathrm{~g}]}\end{array}$ & Fecundity & $\begin{array}{l}W \\
{[\mathrm{~g}]}\end{array}$ & GSI \\
\hline \multirow{9}{*}{$\begin{array}{l}\text { Full Moon } \\
\text { (12 May) }\end{array}$} & 1 & 4.50 & 3.66 & 57 & 0.23 & 0.05 \\
\hline & 2 & 4.50 & 4.03 & 92 & 0.32 & 0.07 \\
\hline & 3 & 4.60 & 3.45 & 49 & 0.27 & 0.06 \\
\hline & 4 & 4.70 & 4.45 & 51 & 0.28 & 0.06 \\
\hline & 5 & 4.80 & 4.40 & - & 0.01 & 0.00 \\
\hline & 6 & 5.00 & 5.40 & 50 & 0.40 & 0.08 \\
\hline & 7 & 5.30 & 5.52 & - & 0.04 & 0.01 \\
\hline & 8 & 5.60 & 6.68 & 77 & 0.64 & 0.11 \\
\hline & Mean & 4.88 & 4.70 & 62.67 & 0.27 & 0.06 \\
\hline \multirow{6}{*}{ Dark Moon (24 May) } & 9 & 4.10 & 3.84 & 30 & 0.01 & 0.00 \\
\hline & 10 & 5.40 & 6.83 & 53 & 0.06 & 0.01 \\
\hline & 11 & 5.40 & 5.98 & 60 & 0.06 & 0.01 \\
\hline & 12 & 5.40 & 6.78 & 50 & 0.19 & 0.04 \\
\hline & 13 & 6.60 & 11.30 & 85 & 0.27 & 0.04 \\
\hline & Mean & 6.36 & 7.89 & 68.13 & 0.17 & 0.03 \\
\hline \multirow{10}{*}{$\begin{array}{l}\text { Waxing } \\
\text { (17 July) }\end{array}$} & 14 & 3.30 & 2.08 & - & 0.03 & 0.01 \\
\hline & 15 & 3.40 & 2.13 & - & 0.02 & 0.01 \\
\hline & 16 & 4.50 & 4.94 & - & 0.08 & 0.02 \\
\hline & 17 & 4.50 & 5.16 & 45 & 0.09 & 0.02 \\
\hline & 18 & 4.60 & 4.37 & 46 & 0.08 & 0.02 \\
\hline & 19 & 4.60 & 5.54 & - & 0.09 & 0.02 \\
\hline & 20 & 4.90 & 5.39 & 60 & 0.14 & 0.03 \\
\hline & 21 & 5.40 & 6.14 & 19 & 0.09 & 0.02 \\
\hline & 22 & 5.70 & 7.73 & 86 & 0.19 & 0.03 \\
\hline & Mean & 4.54 & 4.83 & 51.20 & 0.09 & 0.02 \\
\hline \multirow{9}{*}{$\begin{array}{l}\text { Waning } \\
\text { (31 July) }\end{array}$} & 23 & 5.20 & 3.13 & 64 & 0.29 & 0.06 \\
\hline & 24 & 5.00 & 4.95 & 42 & 0.09 & 0.02 \\
\hline & 25 & 4.90 & 3.25 & 39 & 0.11 & 0.02 \\
\hline & 26 & 4.20 & 3.75 & 102 & 0.28 & 0.07 \\
\hline & 27 & 4.40 & 2.92 & 28 & 0.09 & 0.02 \\
\hline & 28 & 4.70 & 4.23 & 50 & 0.07 & 0.01 \\
\hline & 29 & 4.80 & 3.52 & 55 & 0.13 & 0.03 \\
\hline & 30 & 4.90 & 3.93 & 64 & 0.16 & 0.03 \\
\hline & Mean & 4.76 & 3.71 & 55.50 & 0.15 & 0.03 \\
\hline Overall mean & & 5.04 & 5.11 & 58.87 & 0.17 & 0.03 \\
\hline
\end{tabular}

$\mathrm{SL}=$ standard length; $W=$ whole body weight; $W_{\mathrm{g}}=$ gonad weight; $\mathrm{GSI}=$ gonadosomatic index $=W_{\mathrm{g}} \cdot W^{-1}$. 


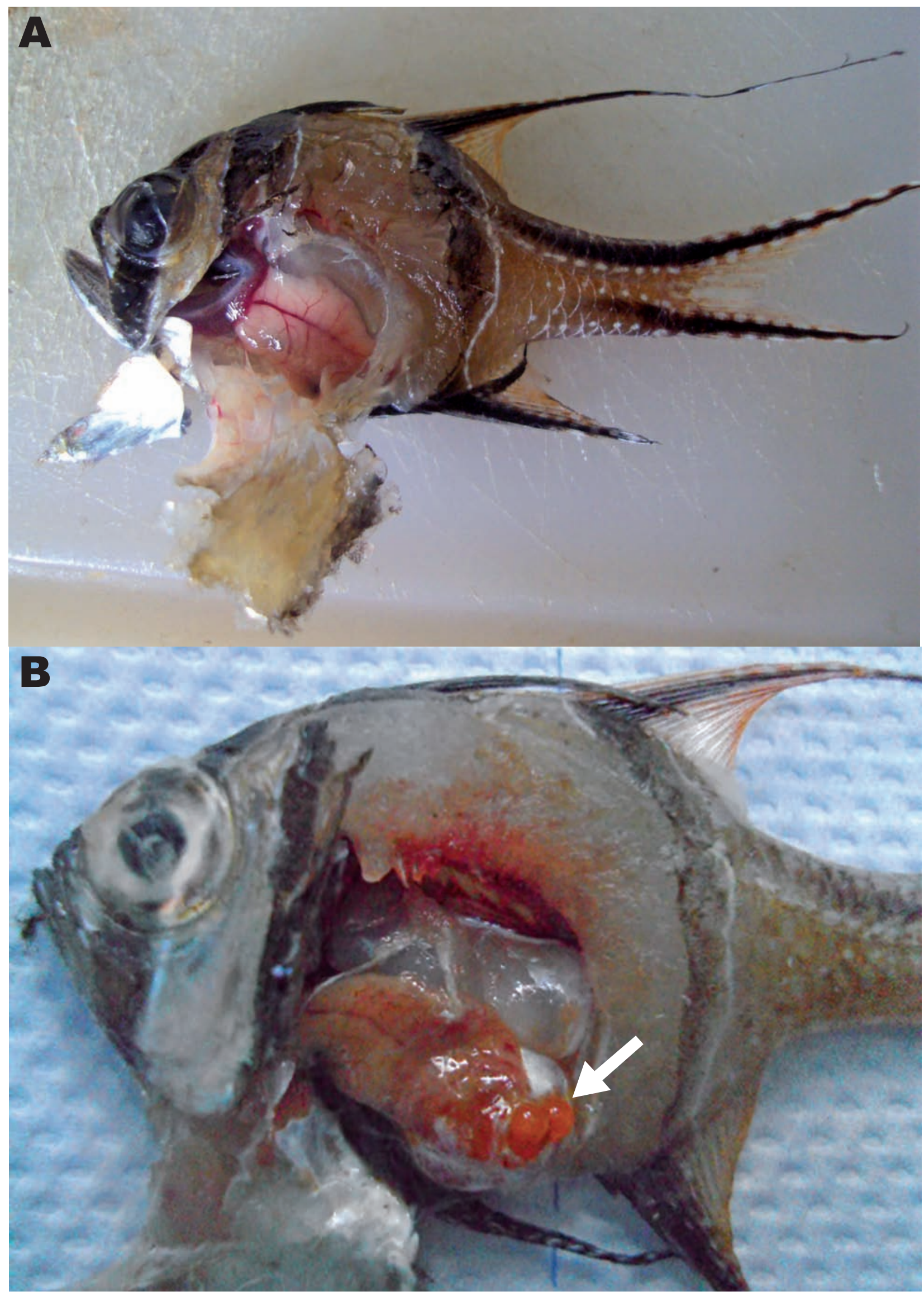

Fig. 7. Mature (single) gonads of male (A) and female (B) Banggai cardinalfish, Pterapogon kauderni, the white arrow indicates a developing egg mass 
Banggai cardinalfish, Pterapogon kauderni, has a longevity of 3-5 years, and that first maturity is reached in a year, at a size of about $4 \mathrm{~cm}$ SL (Table 6, Fig. 7).

There are few estimates of growth parameters in cardinalfishes (Family Apogonidae) with which to compare our results. FishBase (Froese and Pauly 2013) provides growth parameters for only 5 'stocks' in 2 apogonid species, Apogon imberbis (L.) and A. lineatus Temminck et Schlegel, 1842 (Table 9). However, the mean value of $\varnothing '$ (see Equation 2) that can be calculated from these $5 L_{\infty} / K$ pairs $\left(\varnothing^{\prime}=1.911\right)$ matches almost exactly the values of $\varnothing^{\prime}=1.928$ computed from the growth parameters estimated for P. kauderni (Table 9) and hence our growth curves are compatible with what little is known of the growth of cardinalfishes.

Spawning occurs throughout the year, but may be more intensive around September-October. This being the calm season in most of the Banggai Archipelago, P. kauderni appears to behave as predicted by the 'triad hypothesis' of Bakun (1996), as modified by Pauly and Navaluna (1983), which states that fish reproduction, in monsoon-dominated tropical areas, peaks in the lulls between the monsoons. Abesamis and Russ (2010) report a similar pattern for reef fish in the Philippines, with "peaks in density and species richness of recruits during the $[\ldots]$ periods of the year when temperatures were highest and [...] winds were weak". This pattern would explain why recruits have been more commonly observed during field expeditions in October-December (for example during the collection of much of the data used in this analysis) compared expeditions in the early part of the year such as that reported by Vagelli and Erdmann (2002).

This pattern would also suggest that a cohort of P. kauderni hatched in October would reach first maturi-

Table 6

Male Banggai cardinalfish, Pterapogon kauderni, gonad development in Palu Bay $(n=50)$, with bold percentage values for each size class highlighting the relation between size (standard length) and maturation stage

\begin{tabular}{lcccccc}
\hline \multirow{2}{*}{$\begin{array}{l}\text { SL } \\
{[\mathrm{cm}]}\end{array}$} & \multicolumn{4}{c}{ Gonad development stage } & \multicolumn{1}{c}{$n$} \\
\cline { 2 - 6 } & Undeveloped & Developing & Well developed & Mature & Spent & \\
\hline $2.1-2.5$ & $\mathbf{1 0 0}$ & 0.0 & 0.0 & 0.0 & 0.0 & 1 \\
$2.6-3.0$ & $\mathbf{7 5 . 0}$ & 0.0 & 25.0 & 0.0 & 0.0 & 4 \\
$3.1-3.5$ & $\mathbf{6 6 . 7}$ & $\mathbf{1 6 . 7}$ & 0.0 & 16.7 & 0.0 & 6 \\
$3.6-4.0$ & 0.0 & $\mathbf{7 0 . 0}$ & $\mathbf{2 0 . 0}$ & 10.0 & 0.0 & 10 \\
$4.1-4.5$ & 0.0 & 0.0 & $\mathbf{1 2 . 5}$ & $\mathbf{6 2 . 5}$ & 25.0 & 8 \\
$4.6-5.0$ & 0.0 & 0.0 & 6.7 & $\mathbf{6 0 . 0}$ & $\mathbf{3 3 . 3}$ & 15 \\
$5.1-5.5$ & 0.0 & 0.0 & 0.0 & $\mathbf{6 6 . 7}$ & $\mathbf{3 3 . 3}$ & 6 \\
\hline
\end{tabular}

Values shown are the percentage of the age-class sample in each gonad development stage $\mathrm{SL}=$ standard length; $W_{\mathrm{g}}=\mathrm{gonad}$ weight $[\mathrm{g}] ; n=$ number of specimens in each size class; Undeveloped $=\left(W_{\mathrm{g}}<0.2 \mathrm{~g}\right)$; Developing $=\left(W_{\mathrm{g}} \geq 0.2 \mathrm{~g}\right)$; Well developed $=\left(W_{\mathrm{g}} \geq 0.3 \mathrm{~g}\right) ;$ Mature $=\left(W_{\mathrm{g}} \geq 0.5 \mathrm{~g}\right)$.

Table 7

Food items identified in the guts of sub-adult and adult Banggai cardinalfish, Pterapogon kauderni

\begin{tabular}{|c|c|c|c|c|c|}
\hline \multirow{2}{*}{ Food item } & \multirow{2}{*}{$\begin{array}{c}\text { Total No. } \\
\text { of occurrences }\end{array}$} & \multicolumn{3}{|c|}{ Percentage of guts } & \multirow{2}{*}{$\begin{array}{l}\text { Approximate } \\
\text { trophic level }\end{array}$} \\
\hline & & Sub-adult & Adult & Overall & \\
\hline Copepods & 120 & 66.7 & 47.6 & 53.3 & $2.2-3.2^{\mathrm{a}}$ \\
\hline Cypris nauplii & 105 & 88.9 & 23.8 & 46.7 & $2.2-2.6^{\mathrm{b}}$ \\
\hline Conochilus volvox & 90 & 44.4 & 52.4 & 50.0 & $2^{\mathrm{a}}$ \\
\hline Planktothrix agardhii & 70 & 11.1 & 33.3 & 26.7 & $1^{\mathrm{a}}$ \\
\hline Enteromorpha spp. & 45 & 11.1 & 19.0 & 16.7 & $1^{\mathrm{a}}$ \\
\hline Nitzschia spp. & 25 & 11.1 & 9.5 & 10.0 & $1^{\mathrm{a}}$ \\
\hline Asterionella spp. & 25 & 0 & 19.0 & 13.3 & $1^{\mathrm{a}}$ \\
\hline Euglena spp. & 25 & 0 & 23.8 & 16.7 & $1^{\mathrm{a}}$ \\
\hline Allogromia spp. & 20 & 0 & 9.5 & 6.7 & $\approx 2$ \\
\hline Diadema spp. & 20 & 11.1 & 14.3 & 13.3 & $2.4^{\mathrm{b}}$ \\
\hline Desmidium baileyi & 5 & 0 & 4.8 & 3.3 & $1^{\mathrm{a}}$ \\
\hline Unidentified matter & 105 & 55.6 & 57.1 & 56.7 & - \\
\hline
\end{tabular}

Sub-adult $=(\mathrm{SL}<4.2 \mathrm{~cm}, n=9) ;$ adult $=(\mathrm{SL} \geq 4.2 \mathrm{~cm}, n=21) ;{ }^{\mathrm{a}}$ Anonymous $(2008) ;{ }^{\mathrm{b}}$ Pauly and Christensen $(1995)$. 
ty in September of the following year (see also Fig. 6), notwithstanding suggestions that $P$. kauderni reaches first maturity in about 9 months (Vagelli 1999). Indeed, a 9-month lag between hatching and first maturity is hard to conceive for fishes living in the wild, as it would cause successive cohorts to be out of phase with recurrent annual events every 3 out of 4 years.

There are strong indications from the most recent surveys (December 2011 and June 2012, Ndobe et al. unpublished*) that most $P$. kauderni populations in the Banggai Archipelago are declining due to habitat degradation and loss, added to the strong fishing pressure quantified here. Monitoring and management of the fishery as well as addressing habitat loss and degradation (especially the loss of microhabitat, see Moore et al. 2012) are crucial to ensure the conservation of P. kauderni, which is at risk of extinction.

Length-weight relation, other morphometrics and reproductive biology. Growth of Pterapogon kauderni exhibits a negative allometry $(b<3)$. The equation $W=0.18 \cdot L^{2.15}$ obtained for $P$. kauderni is close to the value predicted by the empirical equation for short and deep bodied fish in Froese (2006): $\log a=-1.358 \cdot b+2.322$. A regression using data from 216 mainly juvenile or subadult specimens from Kadongo in Palu Bay (Moore, unpublished data) yielded a value of $b=2.32$, which is also strongly allometric negative and close to the predicted value from Froese (2006).

The morphological data also confirm the results of Vagelli and Volpedo (2004) that there is no significant external morphological difference between male and female $P$. kauderni. The only parameter with a statistically significant difference between male and female $P$. kauderni was the mouthgape (MG/SL) ratio. Despite the high confidence level (99\%) yielded by the ANOVA, the range of values for adult male $P$. kauderni was contained within the range for adult female specimens. The high level of overlap and individual variability in MG/SL values preclude the use of this characteristic for sex determination.

However, subtle sexual dimorphism may be masked by the relatively high variance associated with fin measurements in P. kauderni, itself due to the fact that these fins are extremely vulnerable to damage, especially the caudal and dorsal ones. Indeed fin damage is the main reason for rejection of market-sized specimens by buyers in the ornamental fish trade at the lowest (fishermen) trading level, and the reason why standard-, rather than total length is the reference length throughout this study.

The sex ratio of the sample, of 1.67 males for every female, confirmed Vagelli and Volpedo (2004) who, while finding no significant difference in sex ratio, also had a sample in which the number of males exceeded that of females. A greater number of males would potentially improve reproductive capacity at population level: while female $P$. kauderni are capable of producing eggs on a monthly basis, male $P$. kauderni require a period to recuperate after brooding for almost a month, or in the words of Kolm (2002): "females produce eggs faster than males can 'process' them".

Because of the pair-forming inherent in P. kauderni spawning, sexual maturity does not guarantee participation in reproductive activity. The gonad development data coupled with field observations suggest that reproductive success in P. kauderni may tend to be delayed relative to physical sexual maturity (gonad development), especially in males whose gonad development appears to take place at a smaller size/earlier age than brooding. Kolm (2001) reports that $P$. kauderni females seem to have a preference

Table 8

Food items and food types in the guts of individual groups/classes of Banggai cardinalfish, Pterapogon kauderni

\begin{tabular}{lcc} 
Group/class & $\begin{array}{c}\text { No. of food items } \\
\text { per gut }\end{array}$ & $\begin{array}{c}\text { No. of food types } \\
\text { per gut }\end{array}$ \\
\hline Sub-Adult & $18.3 \pm 8.8$ & $3.0 \pm 1.0$ \\
Adult & $22.4 \pm 12.3$ & $3.1 \pm 1.1$ \\
Overall & $21.8 \pm 11.3$ & $3.1 \pm 0.99$ \\
Brooding males & $30.0 \pm 14.1$ & $3.5 \pm 0.7$ \\
\hline
\end{tabular}

Values are mean \pm standard deviation; sub-adult $=(\mathrm{SL}<4.2 \mathrm{~cm}$, $n=9)$; adult $=(\mathrm{SL} \geq 4.2 \mathrm{~cm}, n=21)$.

Table 9

Growth parameter comparison in three species of cardinalfishes (see text)

\begin{tabular}{lcccl}
\hline Species (sex) & $\begin{array}{c}\mathrm{TL}_{\infty} \\
{[\mathrm{cm}]}\end{array}$ & $\begin{array}{c}K \\
{\left[\mathrm{year}^{-1]}\right.}\end{array}$ & $\emptyset^{\prime}$ & Location; Source \\
\hline Apogon lineatus (F) & 8.5 & 1.23 & 1.949 & Off Niigata Prefecture; Kume et al. (2003) \\
Apogon lineatus (M) & 9.5 & 0.50 & 1.654 & \\
Apogon lineatus (F) & 8.7 & 1.12 & 1.928 & Tokyo Bay; Kume et al. (2003) \\
Apogon lineatus (M) & 11.9 & 0.37 & 1.719 & \\
Apogon imberbis (both) & 15.0 & 0.90 & 2.306 & Mediterranean; Pauly (1978)* \\
Mean & - & - & 1.911 & - \\
Pterapogon kauderni (M, F) & 10.7 & 0.74 & 1.928 & Central Sulawesi; this study \\
\hline
\end{tabular}

* based on data in Garnaud (1962); $\mathrm{TL}_{\infty}=$ total asymptotic length; $\mathrm{K}=$ rate at which asymptotic length is approached in the VBGF (Von Bertalanffy Growth Function); $\varnothing^{\prime}=$ index of growth performance in terms of total length $(\mathrm{TL})=\log (K)+2 \cdot \log \left(\mathrm{TL}_{\infty}\right)$.

\footnotetext{
${ }^{*}$ Ndobe S., Moore A., Salanggon A.I.M., Muslihudin, Setyohadi D., Herawati E.Y., Soemarno. Pengelolaan Banggai cardinalfish (Pterapogon kauderni) melalui Konsep Ecosystem-Based Approach [Banggai cardinalfish (Pterapogon kauderni) Management - an Ecosystem-Based Approach] [In Indonesian]. Article accepted for publication in Jurnal Marine Fisheries (http://journal.ipb.ac.id/index.php/jpsp/index).
} 
for (and produce larger eggs for) larger males. Both Vagelli (1999) and Kolm (2001) report that female $P$. kauderni are active in the courtship process, both in attracting and selecting a mate. This is likely to mean that in a situation where there are sufficient males, smaller males may have to wait (and grow) before mating, even if they are adults in terms of their gonad development.

Spawning does not guarantee reproductive success, as it is not uncommon for male $P$. kauderni to fail to brood to term. In addition, many factors affect recruit survival (Moore et al. 2012, Moore et al. unpublished*). These include the availability of microhabitat, especially sea anemones and Diadema sp. sea urchins, and the prevalence of predation, including cannibalism (observed both in the wild and in captivity, Moore et al. 2012). Recruit and juvenile survival seems to correlate negatively with adult $P$. kauderni density (Moore et al. unpublished*), most likely due to increased levels of cannibalism. Sea anemones (an effective refuge against cannibalism) and sea urchins are being exploited at an unprecedented rate due to recent (over the last 3-6 years) changes in human consumption patterns and their decline seems to have caused sharp declines in the $P$. kauderni population, including at unfished sites, wherever these key microhabitats have been substantially reduced (Moore et al. 2011, 2012, Moore et al. unpublished*).

In view of the complexity of these issues, the biological parameters related to reproductive output (e.g., fecundity/fertility and spawning frequency) are not sufficient to estimate the true resilience or the ability of the species to withstand exploitation. It should be remembered that with no pelagic dispersal stage, sedentary habit and depthrestricted habitat, populations lost through whatever set of circumstances are unlikely to ever recover/return naturally. A population on an island off Liang which had been reduced to 13 individuals by 2004 has not recovered and was locally extinct at this site in June 2012 (Ndobe et al. unpublished**). The high level of genetic population structure over distances as short as 2-5 km (Hoffman et al. 2005, Vagelli et al. 2009) mean that local extinctions can result in the total loss of entire genetic strains and make re-stocking a controversial issue (Ndobe et al. 2012).

Feeding habits. None of the specimens observed had an empty stomach; two brooding males had stomachs that were half full and full, which appears to be incompatible with the assumption (Vagelli 1999) that male Pterapogon kauderni fast while brooding the eggs (around 20 days) and larvae (around 9 days). This phenomenon requires further research; however, this should be based on specimens of opportunity, as the sacrifice of large numbers of brooding males could have a significant impact on the population of this endangered species.

The results in Tables 7 and 8 are consistent with the findings of Vagelli and Erdmann (2002), who, based on gut content analysis of $P$. kauderni collected in the Banggai Archipelago, stated that " $P$. kauderni is a generalist planktivore-carnivore [whose diet includes] representatives from the benthic and neustonic communities", and compatible with the estimated trophic level of P. kauderni \pm SE of $3.3 \pm 0.41$ currently indicated in FishBase (Froese and Pauly 2013). However a surprisingly large number of phytoplankton food items were also observed in the gut tracts of adults, though such items were rare in the gut tracts of sub-adults (Tables 7 and 8).

While crustaceans dominated gut content in terms of volume and number of items in both sub-adult and adult P. kauderni, decapods (cypris stage larvae) were more important in sub-adult gut content and copepods in adult gut content. Adult P. kauderni in Palu Bay appeared to feed on a wider variety of food items than sub-adults (Tables 7 and 8), but this could be an artefact of sample size (21 as opposed to 9 individuals).

Though several taxa recorded by Vagelli and Erdmann (2002) in gut samples from the P. kauderni endemic region (Banggai Archipelago) were not observed during this study, one taxon reported here, apparently for the first time in the diet of P. kauderni, is a sea urchin, most likely the long-spined sea-urchin Diadema setosum. In the Banggai Archipelago, sea urchins are abundant and groups of Diadema setosum provide the most common microhabitat or refuge for P. kauderni, though it has also been observed associated with other urchins of the Family Diadematidae, in particular Echinothrix sp. (Moore et al. 2012).

At the Mamboro site (Palu Bay), where P. kauderni was introduced, sea urchins (including Diadema sp.) are rare. It would therefore be reasonable to assume that the fact they were eaten by over $13 \%$ of the P. kauderni sample could indicate a positive preference. However the natural abundance of Diadema setosum and other members of the Diadematidae in the Banggai Archipelago would indicate that this predation, if it does indeed occur there, does not seriously affect the sea urchin population under natural conditions.

The condition of the items recorded as "unidentified matter" in Tables 7 and 8 was such that these items could not be precisely identified with the resources available. However, in almost all cases small fragments including small fish bones (mostly broken) were visible. While not quantifiable, these observations indicate that small fish do form part of the $P$. kauderni diet, confirming observations of predation of new recruits by adult $P$. kauderni immediately or shortly after release both in captivity and in the wild (Moore et al. 2012). Detailed bone studies and/or genetic (DNA) studies on the gut content of P. kauderni (preferably specimens of opportunity) could no doubt further elucidate the incidence of piscivory including cannibalism in the species. Such a study would also contribute to an informed evaluation of the trophic level of P. kauderni, and, in general, to the further definition of its niche.

\section{ACKNOWLEDGEMENTS}

The research presented forms part of the dissertation by S. Ndobe at the Doctoral Program in the Marine Sciences and Fisheries Faculty Brawijaya University Malang (Indonesia). S. Ndobe acknowledges support from the Directorate of Higher Education of the Ministry of Education

\footnotetext{
* Moore A., Ndobe S., Siddik J., Zamrud M., Salanggon A.I.M., Rahman A. Population status of the endangered endemic marine ornamental Banggai cardinalfish: linked to societal and environmental factors. Paper presented at the International Conference on Marine Sciences, 4-6 June 2013, IPB International Convention Centre, Bogor, Indonesia.

${ }^{* *}$ See footnote on page 247 .
} 
and Culture of the Republic of Indonesia in the form of a travel scholarship to the University of British Columbia (UBC) under the Sandwich Program 2012. Brawijaya University, Malang (Indonesia); Tadulako University, Palu (Indonesia); the Fisheries Centre at UBC, Vancouver (Canada); and the College of Fisheries and Marine Science (Sekolah Tinggi Perikanan dan Kelautan/STPL), Palu (Indonesia) provided in kind support during the research and/or the preparation of this paper. M.L. Palomares and D. Pauly acknowledge support from the Sea Around Us Project, a research collaboration between UBC and the Pew Environment Group. The authors thank two anonymous reviewers for their comments and Ms. Evelyn Liu for the artwork.

\section{REFERENCES}

Abesamis R.A., Russ G.R. 2010. Patterns of recruitment of coral reef fishes in a monsoonal environment. Coral Reefs 29 (4): 911-921. DOI: 10.1007/s00338-010-0653-y

Allen G.R., Donaldson T.J. 2007. Pterapogon kauderni. In: IUCN 2009. IUCN Red List of Threatened Species. Version 2009.1. <www.iucnredlist.org>. [Accessed 22 August 2009]

Anonymous 2008. Lesser Antilles Pelagic Ecosystem (LAPE) project. Trophic levels. FI Institutional Websites. FAO Fisheries and Aquaculture Department [online]. Rome. Updated 28 November 2008. http://www.fao.org/fishery/topic/4210/en [Accessed 6 August 2013].

Bakun A. 1996. Patterns in the ocean: ocean processes and marine population dynamics. California Sea Grant College System, National Oceanic and Atmospheric Administration, in cooperation with Centro de Investigaciones Biológicas del Noroeste.

Froese R. 2006. Cube law, condition factor and weight-length relationships: history, meta-analysis and recommendations. Journal of Applied Ichthyology 22 (4): 241-253. DOI: 10.1111/j.1439-0426.2006.00805.x

Froese R., Pauly D. (eds.) 2013. FishBase. [version 06/2013] http://www.fishbase.org

Hoffman E.A., Kolm N., Berglund A., Arguello J.R., Jones A.G. 2005. Genetic structure in the coral-reef-associated Banggai cardinalfish, Pterapogon kauderni. Molecular Ecology 14 (5): 1367-1375. DOI: $10.1111 /$ j.1365294X.2005.02538.x

Garnaud J. 1962. Monographie de l'Apogon méditerranéen: Apogon imberbis (L.) 1758. Bulletin de l'Institut océanographique de Monaco No. 1248.

Gayanilo F.C., Sparre P., Pauly D. 2005. FAO-ICLARM stock assessment tools II (FiSAT II). Revised version user's guide. FAO Computerized Information Series (Fisheries), No. 8, revised version. Food and Agriculture Organisation of the United Nations (FAO), Rome.

Kolm N. 2001. Females produce larger eggs for large males in a paternal mouthbrooding fish. Proceedings of the Royal Society, Part B: Biological Sciences 268 (1482): 2229-2234. DOI:

Kolm N. 2002. Male size determines reproductive output in a paternal mouthbrooding fish. Animal Behaviour 63 (4): 727-733. DOI: 10.1006/anbe.2001.1959
Kolm N., Hoffman E.A., Olsson J., Berglund A., Jones A.G. 2005. Group stability and homing behavior but no kin group structures in a coral reef fish. Behavioral Ecology 16 (3): 521-527. DOI: 10.1093/beheco/ari022

Kume G., Yamaguchi A., Aoki I. 2003. Variation in life history parameters of the cardinalfish Apogon lineatus. Fisheries Science 69 (2): 249-259. DOI: 10.1046/j.14442906.2003.00615.x

Lunn K.E., Moreau A.-M. 2004. Unmonitored trade in marine ornamental fishes: the case of Indonesia's Banggai cardinalfish (Pterapogon kauderni). Coral Reefs 23 (3): 344-341. DOI: 10.1007/s00338-004-0393-y

Madinawati, Ndobe S., Gamgulu A. 2009. Growth of Banggai cardinalfish Pterapogon kauderni reared at different salinity in a controlled system. Jurnal Akuakultur Indonesia 8 (2): 193-198.

Moore A., Ndobe S. 2007. Discovery of an introduced Banggai cardinalfish population in Palu Bay, central Sulawesi, Indonesia. Coral Reefs 26 (3): 569. DOI: 10.1007/s00338007-0227-9

Moore A., Ndobe S., Salanggon A.-I., Ederyan, Rahman A. 2012. Banggai cardinalfish ornamental fishery: The importance of microhabitat. Proceedings of the 12th International Coral Reef Symposium, "13C Ecological effects of habitat degradation”, 9-13 July 2012, Cairns, Australia. [5 unnumbered pages].

Moore A., Ndobe S., Zamrud M. 2011. Monitoring the Banggai cardinalfish, an endangered restricted range endemic species. Journal of Indonesia Coral Reefs 1 (2): 99-103.

Ndobe S., Setyohadi D., Herawati E.Y., Soemarno, Moore A. 2012. An ecological and social approach to Banggai cardinalfish conservation management. Proceedings of the 12th International Coral Reef Symposium, "17A Science to support the coral triangle initiative", 9-13 July 2012, Cairns, Australia. [5 unnumbered pages].

Pauly D. 1978. A preliminary compilation of fish length growth parameters. Berichte des Institut für Meereskunde an der Universität Kiel, No. 55.

Pauly D. 1980. On the interrelationships between natural mortality, growth parameters, and mean environmental temperature in 175 fish stocks. ICES Journal of Marine Science 39 (2): 175-192. DOI: 10.1093/icesjms/39.2.175

Pauly D. 1983. Some simple methods for the assessment of tropical fish stocks. FAO Fisheries Technical Paper No. 234. Food and Agriculture Organisation of the United Nations (FAO), Rome.

Pauly D. 1984. Fish population dynamics in tropical waters: a manual for use with programmable calculators. ICLARM Studies and Reviews 8. ICLARM, Manila, Philippines.

Pauly D. 2010. Gasping fish and panting squids: Oxygen, temperature and the growth of water-breathing animals. Excellence in Ecology. Book 22. International Ecology Institute, Oldendorf/Luhe, Germany.

Pauly D., Christensen V. 1995. Primary production required to sustain global fisheries. Nature 374 (6519): 255-257. DOI: $10.1038 / 374255 \mathrm{a} 0$

Pauly D., Ingles J. 1981. Aspects of the growth and natural mortality of exploited coral reef fishes. Pp. 89-98. In: Gomez E.D., 
Birkeland C.E., Buddemeier R.W., Johannes R.E., Marsh J.A.jr., Vagelli A.A., Burford M., Bernardi G. 2009. Fine scale disTsuda R.T. (eds.). Proceedings of the 4th International Coral Reef Symposium. Vol. 1. 18-22 May 1981, Manila, Philippines.

Pauly D., Navaluna N.A. 1983. Monsoon-induced seasonality in the recruitment of Philippine fishes. Pp. 823-833. In: Sharpe G.D., Csirke J. (eds.). Proceedings of the expert consultation to examine changes in abundances and species of neritic fisheries resources. FAO Fisheries Report No. 291 (3). Food and Agriculture Organisation of the United Nations (FAO), Rome.

Sachlan M. 1972. Planktonology. Direktorat Jenderal Perikanan Departemen Pertanian, Jakarta, Indonesia. [In Indonesian.]

Vagelli A. 1999. The reproductive biology and early ontogeny of the mouthbrooding Banggai cardinalfish, Pterapogon kauderni (Perciformes, Apogonidae). Environmental Biology of Fishes 56 (1-2): 79-92. DOI: 10.1023/ A:1007514625811

Vagelli A.A. 2008. The unfortunate journey of Pterapogon kauderni: A remarkable apogonid endangered by the international ornamental fish trade, and its case in CITES. SPC Live Reef Fish Information Bulletin 18: 17-28. persal in Banggai cardinalfish, Pterapogon kauderni, a coral reef species lacking a pelagic larval phase. Marine Genomics 1 (3-4): 129-134. DOI: 10.1016/j.margen. 2009.01.001:

Vagelli A.A., Erdmann M.V. 2002. First comprehensive ecological survey of the Banggai cardinalfish, Pterapogon kauderni. Environmental Biology of Fishes 63 (1): 1-8 DOI: 10.1023/A:1013884020258

Vagelli A.A., Volpedo A.V. 2004. Reproductive ecology of Pterapogon kauderni, an endemic apogonid from Indonesia with direct development. Environmental Biology of Fishes 70 (3): 235-245. DOI: 10.1023/B:EBFI.0000033338. 11355.f9

Wetherall J.A. 1986. A new method for estimating growth and mortality parameters from length-frequency data. Fishbyte (ICLARM) 4 (1): 12-14.

Received: 11 April 2013 Accepted: 10 September 2013 Published electronically: 30 September 2013 